\title{
PENGARUH FAKTOR-FAKTOR FUNDAMENTAL KE UANGAN TERHADAP HARGA SAHAM PERUSAHAAN PROPERTI DAN REAL ESTATE YANG TERDAFTAR DI BEI
}

\author{
Firda Silviyatul Husnia \\ Department of Management FEB UMM \\ E-mail: firda.silviatul@gmail.com
}

\begin{abstract}
This study was conducted to determine the effect of factors such as financial fundamentals Earning Per Share (EPS), Return On Assets (ROA), Net Profit Margin (NPM), Debt To Equity Ratio (DER), and Current Ratio (CR) of the company and real property estate listed in Indonesia Stock Exchange during the period 2008-2013. The sampling technique used purposive sampling with a sample of five companies. Variables include the Earning Per Share (EPS), return on assets (ROA), Net Profit Margin (NPM), Debt To Equity Ratio (DER), and Current Ratio $(C R)$ as the independent variable and stock price as dependent variables. Data were analyzed using descriptive statistical analysis and multiple linear regression analysis. The results of this study indicate that the simultaneous regression test (Test F), shows that the Earning Per Share (EPS), return on assets (ROA), Net Profit Margin (NPM), Debt To Equity Ratio (DER), and Current Ratio (CR ) simultaneously influence the stock prices of five companies that were visited. While partial regression test ( $t$ test) showed that the variable EPS, ROA, NPM and CR partial effect, whereas the variable DER has no partial effect on stock prices.
\end{abstract}

Keyword: Stock prices, Earning Per Share (EPS),Return On Equity (ROE), Debt To Equity Ratio (DER), andCurrent Ratio(CR)

\section{PENDAHULUAN}

Investasi dapat diartikan penempatan suatu dana yang kita miliki saat ini dengan harapan akan memberikan keuntungan dimasa yang akan datang. Ketika kita telah memutuskan melakukan investasi setidaknya kita telah merencanakan untuk memiliki kehidupan yang lebih baik untuk kedepannya. Sebelum melakukan investasi, sebaiknya investor terlebih dahulu mengetahui beberapa informasi yang dibutuhkan seperti informasi mengenai harga saham. Hal ini penting karena ketika investor tidak mengetahui informasi apapun mengenai investasi terutama saham, maka bisa saja investor mengalami kerugian. Apalagi saham memang miliki risiko besar sehingga perlu banyak informasi akurat untuk diketahui.

Banyak sekali faktor yang harus diperhatikan terutama ketika berhubungan dengan harga saham. Harga saham memiliki sifat yang sensitive dan selalu berubah-ubah bahkan setiap detiknya. Harga saham yang akan selalu berubah-ubah dipengaruhi oleh dua faktor yaitu 
faktor fundamental dan faktor teknikal.

Faktor yang menitik beratkan pada data-data kunci dalam laporan keuangan untuk memperhitungkan apakah harga saham sudah terapresiasi secara akurat. Sedangkan factor secara teknikal memberikan informasi kepada investor dan calon investor untuk menentukan kapan pembelian saham dilakukan dan pada saat kapan saham harus dijual (Kodrat, 2010:203).

Crabb (2003) menyatakan : "Fundamental analysis is an examination of corporate accounting reports to asses the value of company, that investor can use to analysze a company's stock prices “. Pernyataan ini menunjukkan bahwa informasi akuntansi atau laporan keuangan yang perusahaan dapat digunakan oleh investor sebagai faktor fundamental untuk menilai harga saham perusahaan. Selain itu, rasio keuangan juga dapat digunakan sebagai faktor fundamental untuk menilai harga saham.

Dari berbagai pernyataan diatas, sudah pasti faktor fundamental memiliki peran yang sangat dominan dalam pengaruhnya terhadap harga saham. Dunia global menuntut semua aspek untuk bisa berkembang dengan meningkatkan kinerja dan produktivitas agar mampu bertahan dan bersaing dalam persaingan yang semaik lama semakin ketat, hal ini berlaku juga pada Bursa Efek Indonesia (BEI). Bursa Efek Indonesia memiliki banyak sektor didalamnya dan semua sektor juga dituntut untuk bisa berkembang. Salah satu sektor yang berada dalam BEI adalah Sektor Properti dan Real Estate menarik untuk dijadikan obyek dalam penelitian ini karena sektor ini memiliki prospek yang sangat bagus dan mampu berkembang dengan pesat. Ketika sektor ini mampu berkembang pesat, sudah pasti jumlah saham akan tumbuh pesat.Bisa kita perhatikan pula beberapa tahun ini banyak sekali perumahan, apartemen, ruko, dan mall yang dibangun menjulang tinggi.

Hal ini juga membuktikan bahwa sektor properti sangat prospek untuk dikembangkan sesuai dengan kebutuhan manusia yang semakin bertambah. Jakarta sebagai ibu kota Indonesia juga merupakan kota yang memiliki prospek sangat bagus untuk sektor ini. Sampai saat ini, berita tentang perkembangan sektor properti dan real estate masih selalu dimuat di surat kabar.

Berita yang selalu mengejutkan adalah Indonesia utamanya Jakarta sebagai ibu kota menjadi tujuan investor untuk berinvestasi, karena sektor properti dan real estate berkembang sangat drastis di Jakarta. Berbagai tipe mulai dari yang biasa, menengah hingga mewah selalu laku terjual.

Menurut kabar yang dikutip dalam lipsus.kontan.co.id menyatakan bahwa Jakarta menempati posisi teratas di kawasan Asia Pasifik. Lembaga yang berbasis di Washington DC yaitu PriceWaterhouseCoopers (PwC) dan Urban Land Institute, sesuai dengan hasil survey menyatakan bahwa Jakarta merupakan tempat yang tepat untuk melakukan investasi.

\section{TINJAUAN PUSTAKA}

Investasi menurut Ikatan Akuntansi Indonesia merupakan satu aktiva yang dipakai perusahaan untuk 
mengembangkan kekayaan lewat distribusi hasil investasi (seperti: bunga, royalty dan deviden). Umumnya investasi dibedakan menjadi dua, yaitu: investasi pada aset-aset finansial (financial assets) dan investasi pada aset-aset riil (real assets).

Investasi pada asset-aset finansial dilakukan di pasar uang dan di pasar modal. Sedangkan investasi pada asset-aset riil dapat berbentuk pembelian aset produktif, pendirian pabrik, pembukaan pertambangan dan lainnya (Halim, 2005:4). Saat melakukan investasi di pasar modal, investor harus benar-benar menyadari bahwa disamping akan memperoleh keuntungan tapi juga kemungkinan akan mengalami kerugian. Keuntungan atau kerugian tersebut sangat dipengaruhi oleh kemampuan investor menganalisis keadaan harga saham dan kemungkinan turunnaiknya harga di bursa.

Analisis yang Fundamental memiliki hubungan erat kaitannya dengan suatu kegiatan perusahaan termasuk efisiensi dan efektifitas perusahaan itu untuk mencapai tujuan perusahaan tersebut. Secara umum faktor fundamental yang diteliti dalam memprediksi harga saham di masa yang akan datang dengan menggunakan rasio keuangan. Tujuan analisis fundamental untuk menentukan apakah nilai saham berada pada posisi underpriced atau overpriced.

Rasio keuangan digunakan
untuk mengurangi banyaknya
informasi relevan pada serangkaian
indikator keuangan yang terbatas.
Rasio keuangan didesain untuk
memperlihatkan hubungan antara
item-item pada laporan keuangan

(Kodrat, 2010:234). Dalam investasi, rasio keuangan dapat digunakan untuk melihat hasil kegiatan suatu emiten yakni antara lain : EPS, ROA, NPM, DER, dan CR.

Menurut Siamat (1995:385), Saham atau stocks adalah surat bukti atau tanda kepemilikan bagian modal pada suatu perseroan terbatas. Dalam transaksi jual beli di bursa efek, saham atau sering disebut shares merupakan instrument yang paling dominan diperdagangkan. Saham tersebut dapat diterbitkan dengan cara atas nama atau atas unjuk.

Pada Pendekatan harga saham di BEI sangat mempengaruhi keputusan-keputusan para investor dalam hal memutuskan investasinya, maka seorang investor perlu informasi yang jelas baik secara individu ataupun kelompok.. Terutama informasi pada harga saham penutupan, dimana ialah harga saham terakhir kali pada saat berpindah tangan di akhir perdagangan. Harga penutupan mungkin akan menjadi harga pasar (Halim,2005:16).

Pengukuran harga saham mengggunakan faktor fundamental emiten seperti EPS, ROA, NPM, DER, dan CR akan dijelaskan secara rinci sebagai berikut: Pengaruh Earning Per Share (EPS) terhadap harga saham. Menurut Brigham (2012:151), EPS yang besar menunjukkan bahwa kemampuan perusahaan yang lebih besar dalam menghasilkan keuntungan bersih dari setiap lembar saham. Peningkatan EPS menandakan bahwa perusahaan berhasil meningkatkan kemakmuran para investor. Akibatnya akan terjadi kenaikan laba yang pada akhirnya ada kecenderungan kenaikan harga 
saham, begitu juga sebaliknya. Ketika laba yang dimiliki perusahaan menurun, maka Earning Per Share (EPS) yang dimilik perusahaan akan mengalami penurunan.

Pengaruh Return On Asset (ROA) terhadap harga saham Return On Asset (ROA) merupakan salah satu ukuran pengembalian atas aktiva yang dimiliki perusahaan. Ketika ROA meningkat berarti kinerja perusahaan semakin baik dan sebagai dampaknya harga sahan perusahaan semakin meningkat, begitu juga sebaliknya.

Pengaruh Net Profit Margin (NPM) terhadap harga saham NPM merupakan perbandingan laba bersih dengan penjualan perusahaan. Rasio ini menunjukkan seberapa efisien perusahaan dalam mengelola penjualannya dalam mencapai laba. Semakin tinggi nilai NPM semakin efisien perusahaan tersebut mendapatkan sebuahh laba dari penjualan.sehingga harga saham akan naik, begitu juga sebaliknya.
Pengaruh Debt to Equity Ratio (DER) terhadap harga saham dan mengidentifikasikan sejauh mana perusahaan dapat menanggung kerugian tanpa harus membahayakan kepentingan krediturnya. Jika DER meningkat maka menunjukkan kinerja perusahaan yang semakin memburuk. Akibatnya adalah investor akan mempertimbangkan membeli saham perusahaan tersebut, sehingga harga saham perusahaan itu akan turun.

Pengaruh Current Ratio (CR) terhadap harga saham Current Rasio merupakan salah satu ukuran likuiditas yang bertujuan untuk mengukur kemampuan perusahaan untuk melunasi kewajiban jangka pendeknya. Nilai Current Ratio (CR) yang rendah akan berakibat pada menurunnya harga pasar saham perusahaan yang bersangkutan.

Berdasarkan teori yang telah dijelaskan diatas, maka kerangka berfikir dalam penelitian ini dapat dilihat pada gambar 1 .

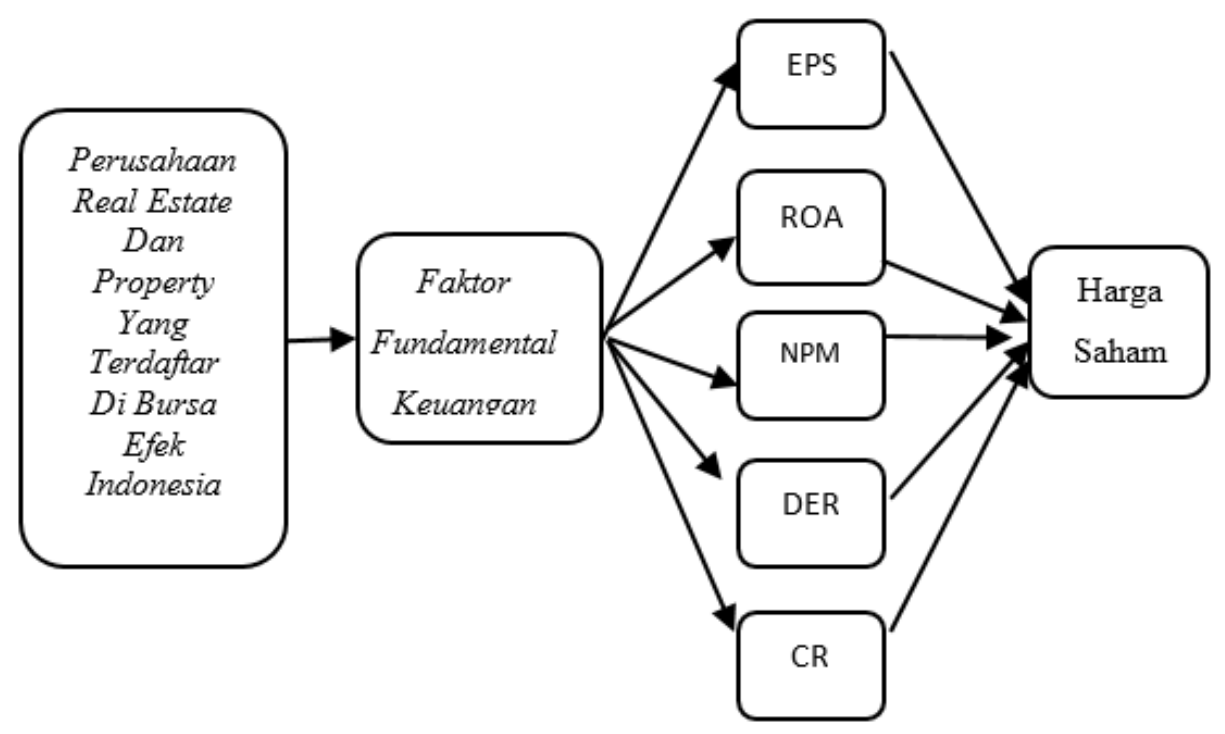

Gambar 1. Kerangka Konsep penelitian 


\section{METODE PENELITIAN}

Jenis penelitian dalam penelitian ini adalah berbentuk deskriptif kuantitatif, maksudnya dalam penelitian ini untuk mencari kecil atau besarnya suatu pengaruh terhadap suatu objek yang diteliti.

Penelitian inimemiliki dua variabel yakni variabel dependen dan independen. Variabel terikat atau variabel tergantung (dependent variable) adalah variabel yang dipengaruhi oleh variabel lain.

Sedangkan variable bebas (independent variable) adalah variabel yang mempengaruhi variabel lain. Variabel bebas (independent variable) meliputi EPS (X1), ROA (X2), NPM (X3), DER(X4), CR(X5). Variabel terikat sama dengan Harga Saham (Y).

Populasi penelitian ini adalah seluruh perusahaan Property dan Real estate yang terdaftar di BursaEfek Indonesia. Teknik pengambilan sampel (sampling) yang digunakan dalam penelitian ini adalah purposive sampling. Jenis data dalam penelitian ini adalah data objek yaitu data secara fisik kita amati, dicatat, serta diklasifikasikan. Adapun sumber data dalam penelitian ini adalah data sekunder.

Data yang dikumpulkan menggunakan teknik dokumentasi dengan cara melakukan pencatatan dan mengevaluasi data peneliti terdahulu dan studi kepustakaan sesuai dengan penelitian ini. Teknik analisis data adalah mendeskripsikan teknik analisis apa yang akan digunakan oleh peneliti untuk menganalisis data yang telah dikumpulkan, termasuk pengujian (Sanusi, 2011:11). Menurut Sanusi (2011), statistik deskriptif adalah penyajian data dengan tabel, grafik, diagram lingkaran, pictogram, perhitungan modus, median, mean, persentase dan standar deviasi. Regresi liner berganda pada dasarnya merupakan perluasan dari regresi linear sederhana, yaitu menambah jumlah variabel bebas yang sebelumnya hanya satu menjadi dua atau lebih variabel bebas.

Penelitian ini memiliki empat variabel bebas dan satu varabel terikat. Sehingga dengan hal ini regresi linear berganda dinyatakan dalam persamaan matematis sebagai berikut:

$$
Y=\alpha+\underset{b_{4} X_{4}}{b_{1} X_{1}+b_{2} X_{2}+b_{3} X_{3}+}
$$

Pengujian secara simultan, Uji statistik $\mathrm{F}$ digunakan untuk menguji kepastian pengaruhdari seluruh variabel independen secara bersamasama Kriteria pengujian hipotesis untuk uji statistik $F$ Bila Fsignifikan $<0,05$ maka secara simultan berpengaruh. Bila Fsignifikan $>0,05$ maka secara simultan tidak berpengaruh.

Pengujian secara parsial (Uji Statistik T). Uji statistik T digunakan untuk menguji pengaruh secara parsial antara variabel independen dengan asumsi bahwa variabel lain dianggap konstan. Kriteria pengujian uji $\mathrm{t}$ adalah Bila tsignifikan $<0,05$ maka secara parsial berpengaruh namun bila tsignifikan> 0,05 maka secara parsial tidak berpengaruh.

\section{HASIL PENELITIAN DAN PEMBAHASAN}

Perusahaan Property dan Real Estate yang terdaftar di Bursa Efek Indonesia sebanyak 46 perusahaan, 
namun hanya 5 perusahaan saja yang memenuhi seluruh kriteria purposive sampling dalam penelitian ini yaitu PT Alam Sutera Realty Tbk, PT Sentul City Tbk, PT Bumi Serpong Damai Tbk, PT Bakrieland Development Tbk, dan PT Lippo Karawaci Tbk.

Hasil regresi linear berganda dengan menggunakan SPSS versi 15.00 sebagai berikut:

$$
Y=90,980+5,317 X 1+43,993
$$

$\mathrm{X} 2-8,965 \mathrm{X} 3+78,933 \mathrm{X} 4+46,737 \mathrm{X} 5$

Gejala Heteroskedastisitas digunakan untuk mengetahui apakah masing-masing variabel bebas memiliki gejala heteroskedastisitas, dalam penelitian ini tidak terjadi gejala heteroskedastisitas.

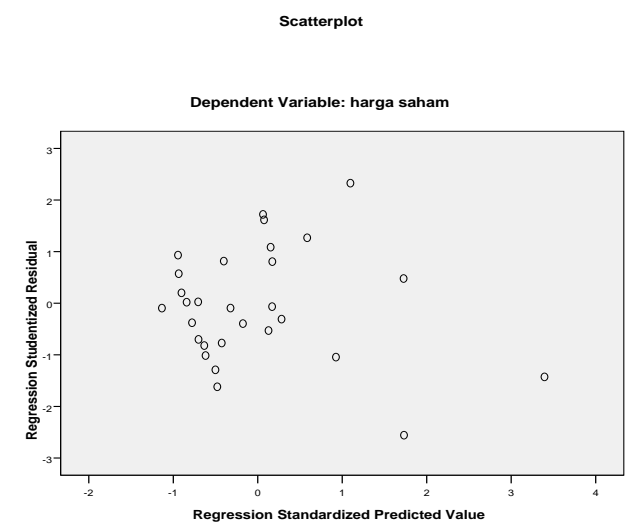

Gejala autokorelasi perlu diketahui dengan tujuan mengetahui apakah dalam model regresi linear ada korelasi antara kesalahan pengganggu pada periode $t$ dengan kesalahan pada periode $\mathrm{t}-1$ (sebelumnya). Dalam penelitian ini nilai Durbin Watson (DW) sebesar 1,505 nilai DW berada diantara -2 sampai 2menunjukkan tidak terjadi autokorelasi dalam penelitian ini.
Gejala Multikolinearitas dapat diketahui dengan melihat nilai Variance Inflating Factor (VIF) dari hasil analisis regresi, Jika nilai VIF > 10 maka terdapat gejala mutikolinearitas yang tinggi. Penelitian ini menunjukkan seluruh nilai Variance Inflating Factor (VIF) $<$ 10. EPS memiliki VIF sebesar 9,935; ROA sebesar 3,826; NPM sebesar 1,682; DER sebesar 1,214; dan CR sebesar 1,071 sehingga tidak terjadi multikolinearitas.

Uji normalitas digunakan untuk menguji nilai residual yang dihasilkan oleh regresi berdistribusi normal atau tidak. Penelitian ini data berdistribusi normal. Persamaan regresi linear berganda semakin baik apabila nilai koefisien determinasi (R2) semakin besar (mendekati 1).bahwa nilai Adjusted $R$ Square adalah sebesar 0,820 atau $82 \%$. Nilai ini menunjukkah bahwa kemampuan variabel bebas dalam menjelaskan varians dari variabel terikatnya adalah sebesar $82 \%$. Sedangkan sisanya sebesar $18 \%$ dijelaskan oleh variabel lain.

Output uji $\mathrm{F}$ dalam peneltian ini menunjukkan bahwa $\mathrm{F}_{\text {signifikan }}<$ 0,05 maka kelima variabel bebas yaitu EPS, ROA, NPM, DER dan CR secara simultan berpengaruh terhadap variabel terikat (harga saham). Output dalam penelitian ini menunjukkan bahwa hanya ada satu variabel yang tidak berpengaruh secara parsial yaitu DER, karena nilai tsignifikan keduanya $>0,05$. Sedangkan sisanya EPS, ROA, NPM, dan CR memiliki pengaruh secara parsial.

Hasil pengujian regresi linear berganda menunjukkan bahwa variabel independen EPS, ROA, 
NPM, DER dan CR secara simultan berpengaruh terhadap harga saham perusahaan Properti dan Real Estate yang terdaftar di Bursa Efek Indonesia selama periode 2008-2013. Hasil ini mendukung penelitian Oktavia Dewi Yanti dan Faruq Ghozali bahwa semua variabel berpengaruh secara bersama-sama atau simultan. Namun menolak hasil penelitian Laksmi Savitri Megarini. Sedangkan jika kita melihat hasil uji parsial (uji t).

Pengaruh EPS terhadap harga saham. Hasil penelitian menunjukkan bahwa EPS memiliki pengaruh terhadap harga saham, Hasil ini mendukung penelitian Oktavia Dewi Yanti dan Faruq Ghozali dan menolak hasil penelitian Kurnianto.

Hasil penelitian menunjukkan bahwa ROA berpengaruh terhadap harga saham, Hasil penelitian ini mendukung hasil penelitian Oktavia Dewi Yanti dan Faruq Ghozali menolak hasil penelitian Kurnianto. Dalam penelitian ini NPM memiliki pengaruh terhadap harga saham. Hasil penelitian ini menolak hasil penelitian Oktavia Dewi Yanti.

Pengaruh DER terhadap harga saham dalam penelitian ini DER tidak memiliki pengaruh terhadap harga saham. Hasil penelitian ini mendukung hasil penelitian Kurnianto dan Faruq Ghozali. Dalam penelitian ini CR memiliki pengaruh terhadap harga saham, Hasil penelitian ini menolak hasil penelitian Kurnianto.

\section{SIMPULAN}

Secara simultan faktor fundamental keuangan yang meliputi EPS, ROA, NPM, DER dan CR perpengaruh signifikan terhadap harga saham perusahaan sektor property dan real estate yang tercatat di Bursa Efek Indonesia selama tahun 2008-2013.

Secara parsial faktor fundamental keuangan EPS, ROA, NPM, dan CR berpengaruh signifikan terhadap harga saham. Sedangkan DER tidak berpengaruh signifikan terhadap harga saham perusahaan sektor property dan real estate yang tercatat di Bursa Efek Indonesia selama tahun 2008-2013.

\section{DAFTAR PUSTAKA}

Ahmad, Kamaruddin. 1996. Dasardasar Manajemen Investasi. Rineka Cipta. Jakarta

Anoraga, Pandji dan Piji Pakarti. 2006. Pengantar Pasar Modal. Rineka cipta. Jakarta.

Brigham, Eugene F dan Houston, Joel F. 2012. Dasar-dasar Manajemen Keuangan. Buku 1 Edisi 11. Salemba Empat. Jakarta.

Crabb, Peter R. 2003. "Finance and Investment using The Wall Street Journal", McGraw-Hill, New York.

Fakhruddin, $\mathbf{M}$ dan Hadianto, $\mathbf{M}$ Sopian. 2001. Perangkat dan Model Analisis Investasi di Pasar Modal. Gramedia. Jakarta.

Halim, Abdul dan Sarwoko. 1995. Manajemen Keuangan. UPP AMP YKPN. Yogyakarta.

Halim, Abdul. 2005. Analisis Investasi. Buku 1 Edisi 2. Salemba Empat. Jakarta.

Husnan, Suad.2003. Dasar-Dasar Teori Portofolio dan Analisis sekuritas. AMPYKPN. Yogyakarta.

Kasmir. 2010. Pengantar manajemen 
Keuangan. Kencana Prenada Media Group. Jakarta.

Kodrat, David Sukardi. 2010. Manajemen Investasi Pendekatan Teknikal dan Fundamental untuk Analisis Saham. Graha Ilmu. Yogyakarta.

Muis, Saludin.2008. Meramal Pergerakan Harga Saham.Graha Ilmu. Yogyakarta.

Siamat, Dahlan. 1995. Manajemen Lembaga Keuangan. Intermedia. Jakarta

Sunariyah. 1997. Pengetahuan Pengantar Pasar Modal.UPP AMP YKPN. Yogyakarta.

Sunariyah. 2003. Pengantar Pasar Modal. Salemba Empat. Jakarta.

Sanusi, Anwar. 2011. Metodologi Penelitian Bisnis. Salemba Empat. Jakarta.

Sutrisno. 2009. Manajemen Keuangan Teori Konsep dan Aplikasi.Cetakan Ketujuh. Ekoisia. Yogyakarta.

Zubir, Zalim. 2011. Manajemen Portofolio Penerapan dalam
Investasi Saham. Salemba Empat. Jakarta.

Jawa Pos, 12 November 2014, hal 19 www.idx.co.id, diakses 25 Maret 2014 pukul 15.00 WIB

jurnal-okta.pdf, diakses 25 Maret 2014 pukul $15.00 \mathrm{WIB}$

faruq ghozali.pdf, diakses 25 Maret 2014 pukul $15.00 \mathrm{WIB}$

kurnianto.pdf, diakses 25 Maret 2014 pukul 15.00 WIB

ratna febriasari otomotif.pdf, diakses 25 Maret 2014 pukul $15.00 \mathrm{WIB}$

laksmi safitri.pdf, diakses 25 Maret 2014 pukul 15.00 WIB

www.bapepam.go.id, diakses 20 April 2014 pukul 12.00 WIB siti-syahibah.blogspot.com, diakses 15 oktober 2014 pukul 16.30

lipsus.kontan.co.id, diakses 23

Oktober 2014 pukul 09.00 WIB

www.kompas.com,diakses 23

Oktober 2014 pukul 09.00 WIB

http://jurnal-sdm.blogspot.com, diakses 23 Oktober 2014 pukul 09.00 WIB 